\title{
Should divorce be easier or harder?
}

\section{The evidence, though weak, favors legal, easy, unilateral divorce}

Keywords: divorce, female labor supply, family law, marriage, fertility

\section{ELEVATOR PITCH}

Many countries have enacted legislation over the past few decades making divorce easier. Some countries have legalized divorce where it had previously been banned, and many have eased the conditions required for a divorce, such as allowing unilateral divorce (both spouses do not have to agree on the divorce). Divorce laws can regulate the grounds for divorce, division of property, child custody, and child support or maintenance payments. Reforms can have a range of social effects beyond increasing the divorce rate. They can influence female labor supply, marriage and fertility rates, child well-being, household saving, and even domestic violence and crime.

\section{KEY FINDINGS}

\section{Pros}

( Even though unilateral divorce leads to a larger number of divorces in the short term, it probably leads to better quality (if fewer) marriages in the long term.

( L Legalizing divorce leads to increases in labor force participation among married women.

$\oplus$ Easier divorce-both legalization and allowing unilateral divorce-leads to higher household saving rates.

๑ Unilateral divorce is associated with lower rates of domestic violence and female suicide.
Rise in divorce rates after reforms, 1960-2018

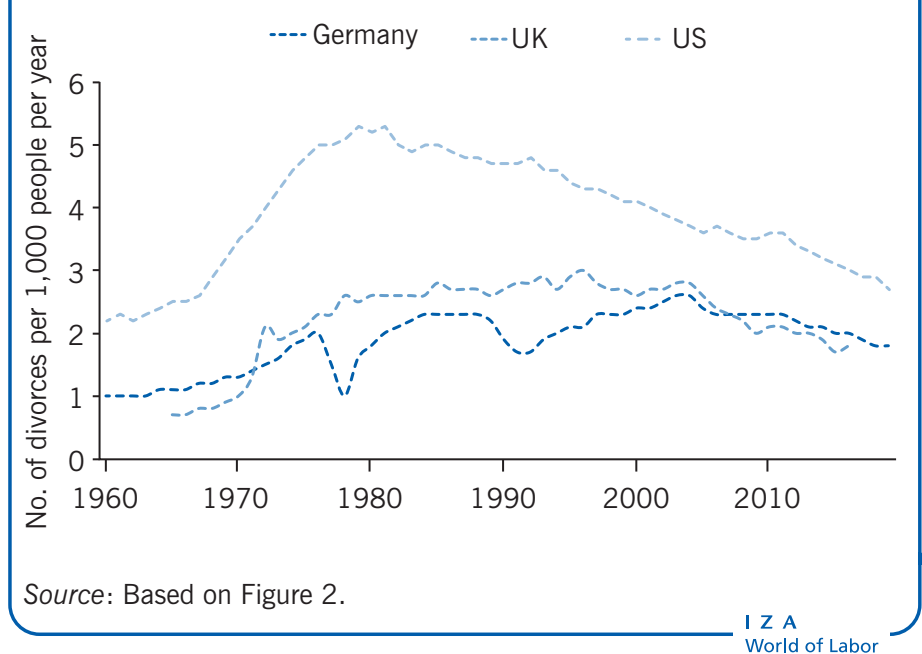

\section{Cons}

- Unilateral divorce leads to lower fertility and other marriage-specific investments.

- Where the law requires splitting marital assets equally between spouses, allowing unilateral divorce may lead to a reduction in female labor supply.

- Both legalizing divorce and allowing for unilateral divorce may lead to worse long-term child outcomes, including educational attainment and adult income.

- Unilateral divorce may increase the incidence of criminal behavior among children born slightly before and hence affected by the changes in divorce law.

\section{AUTHOR'S MAIN MESSAGE}

Today, divorce is legal in almost all countries, so the relevant policy issues are how much to lower the costs of divorce and whether to require the consent of both spouses. The evidence makes a (weak) case in favor of legal, easy, unilateral divorce, which leads to better marriages, higher household savings, and even lower rates of domestic violence. However, unilateral divorce combined with equal division of property may depress female employment, which policymakers may seek to avoid. And because there is some evidence that unilateral divorce may harm children in the long term, easy divorce should be accompanied by other policies aimed at supporting children in vulnerable families. 


\section{MOTIVATION}

Almost every country in the world has laws regulating how to end a marriage. Many countries have made changes to their divorce legislation in recent decades, usually in the direction of facilitating the dissolution of marriages. Some countries have legalized divorce only recently (e.g. Malta in 2011, Chile in 2004, Ireland in 1996, and Spain in 1981). In the 1960s and 1970s, it was common for national legislation to allow divorce only in very restricted cases, usually requiring that one spouse provide proof that the other had committed a serious marital fault, such as adultery, domestic violence, or abandonment. Over time, more and more countries have allowed no-fault divorce, often requiring as grounds only the claim of "irretrievable breakdown" of the marital relationship (or "irreconcilable differences") or even just the consent of both spouses. Finally, many countries in recent years have introduced unilateral divorce, so that the divorce is granted even without the consent of the other spouse.

\section{No-fault and unilateral divorce laws}

No-fault divorce laws allow a court to grant a divorce without requiring the petitioner to provide evidence that the spouse has committed a breach of the marital contract (some form of wrongdoing). No-fault divorce can require mutual consent (both partners must agree) or allow for unilateral divorce.

Unilateral divorce laws allow one spouse to obtain a divorce without the consent of the other spouse.

Does divorce law matter? What should legislators keep in mind when considering divorce law reforms? Several different aspects of divorce can be regulated by divorce law: grounds for divorce, division of property, child custody, and child support or maintenance payments. The economics literature has examined several effects of divorce laws, starting with divorce rates. It has also looked at a broader range of social outcomes potentially affected by divorce laws that go well beyond marriage breakup rates, including impacts on female labor supply, marriage and fertility rates, child well-being, household saving, and even domestic violence and crime. Each of these broader social outcomes is discussed below.

\section{Common types of property division in divorce}

Title-based regimes of property division allocate the assets of divorcing couples between divorcing spouses according to who holds ownership title of each asset.

Community property regimes divide marital assets and debts equally between divorcing spouses.

Equitable distribution regimes leave discretion to the courts in dividing the assets of divorcing spouses, in order to achieve "equity" or protect the more vulnerable party.

\section{DISCUSSION OF PROS AND CONS}

There are four main policy options related to the grounds for divorce: banning divorce (currently not on the table in most countries), allowing divorce only on grounds of fault, 
requiring mutual consent, and allowing for unilateral divorce. In each case, a married couple may have to meet other conditions before a divorce is granted, such as a requirement that spouses separate for a set period of time. Some countries allow couples to file for divorce on multiple grounds, thus allowing for fault, mutual consent, and unilateral divorces in parallel, each with different requirements and costs. Figure 1 summarizes the main reforms in the grounds for divorce in 18 European countries between 1950 and 2015. Four of the countries (Italy, Portugal, Spain, and Ireland) legalized divorce in or after 1970, while all 18 countries had introduced no-fault grounds before 2000. Only three allowed for unilateral divorce with no separation requirement by 2010 (Sweden, Finland, and Spain), while others have gradually decreased their separation requirements (Italy being the most recent in 2015) [1].

Figure 1. Main divorce law reforms in Europe, 1950-2019

\begin{tabular}{|c|c|c|c|c|}
\hline \multirow[b]{2}{*}{ Country } & \multirow[b]{2}{*}{$\begin{array}{c}\text { Divorce } \\
\text { legalization }\end{array}$} & \multirow[b]{2}{*}{ No-fault divorce } & \multicolumn{2}{|c|}{ Unilateral divorce } \\
\hline & & & $\begin{array}{l}\text { Separation } \\
\text { required }\end{array}$ & $\begin{array}{c}\text { No separation } \\
\text { required }\end{array}$ \\
\hline Austria & & & 1978 & \\
\hline Belgium & & & $1975(1983,2000)$ & \\
\hline Denmark & & & 1969 (1989) & \\
\hline Finland & & & & 1988 \\
\hline France & & 1976 & 1976 (2005) & \\
\hline Germany & & & 1977 & \\
\hline Greece & & 1979 & 1983 & \\
\hline Iceland & & & 1993 & \\
\hline Ireland & 1996 & 1996 & & \\
\hline Italy & 1970 & 1975 & 1970 (2015) & \\
\hline Luxembourg & & & 1979 & \\
\hline Netherlands & & 1971 & 1971 & \\
\hline Norway & & & (1993) & \\
\hline Portugal & 1976 & 1976 & 1976 (2008) & \\
\hline Spain & 1981 & 1981 & 1981 & 2005 \\
\hline Sweden & & & & 1973 \\
\hline Switzerland & & & 2000 & \\
\hline UK & & 1973 & 1973 (1984) & \\
\hline
\end{tabular}

Notes: For "Divorce legalization" and "No-fault divorce" the missing entries mean reforms were pre-1950. For "Unilateral divorce" only Ireland has not adopted this reform. The years in parentheses indicate subsequent reforms that reduced the length of the separation requirement.

Source: González, L., and T. Viitanen. "The effect of divorce laws on divorce rates in Europe." European Economic Review 53:2 (2009): 127-138 [1], modified version of Table 1.

In addition, divorce law also regulates the division of property after the dissolution of the marriage. The three main systems are separation of property (or "title-based" regimes), community property, and equitable distribution. The law may or may not allow for fault considerations to affect the distribution, and the courts may be granted different degrees of discretion over the allocation of assets between the spouses.

Other policy options involve rules for the custody of children. Before the 1970s, legislation in many countries favored sole custody by one parent, typically the mother. In recent decades, however, most of them have introduced reforms favoring joint custody by 
both partners. There may also be rules regarding child support payments from the noncustodial parent to the custodial parent or maintenance payments to a spouse (alimony), along with specified enforcement mechanisms.

Many countries have considered or implemented reforms to their divorce laws in recent years, with the policy discussions covering some or all of the aspects just mentioned. Some proposed reforms include reverting to "harder" divorce.

Much of the recent economics research on the effects of divorce law has focused on the introduction of no-fault, unilateral divorce in the US, which happened at different times across different states in the country. Most of the reforms took place during the 1970s and 1980s: between 1968 and 1988, 29 states that had previously required mutual consent introduced unilateral divorce [2]. Some studies have exploited recent reforms across European countries, using the variation illustrated in Figure 1.

\section{Divorce rates}

The first-order question regarding the social effects of divorce laws would seem to be whether the recent liberalization of the grounds for divorce has affected divorce rates. During the 1960s and 1970s, divorce rates rose in the US, the UK, Germany, and France (Figure 2). The trend was reversed in the US after 1980 and in the UK after 1995, while the increase was sustained until the mid-2000s in France, Germany, and, most notably, Italy. The US had the highest divorce rates of the six countries during the whole period 1960-2019, rising from about two divorces a year per 1,000 people in 1960 to more than five in 1980 and then falling to about three in 2017. Italy had the lowest incidence of divorce during the whole period 1970-2019, with less than one divorce per 1,000 people

Figure 2. Crude divorce rate for six countries

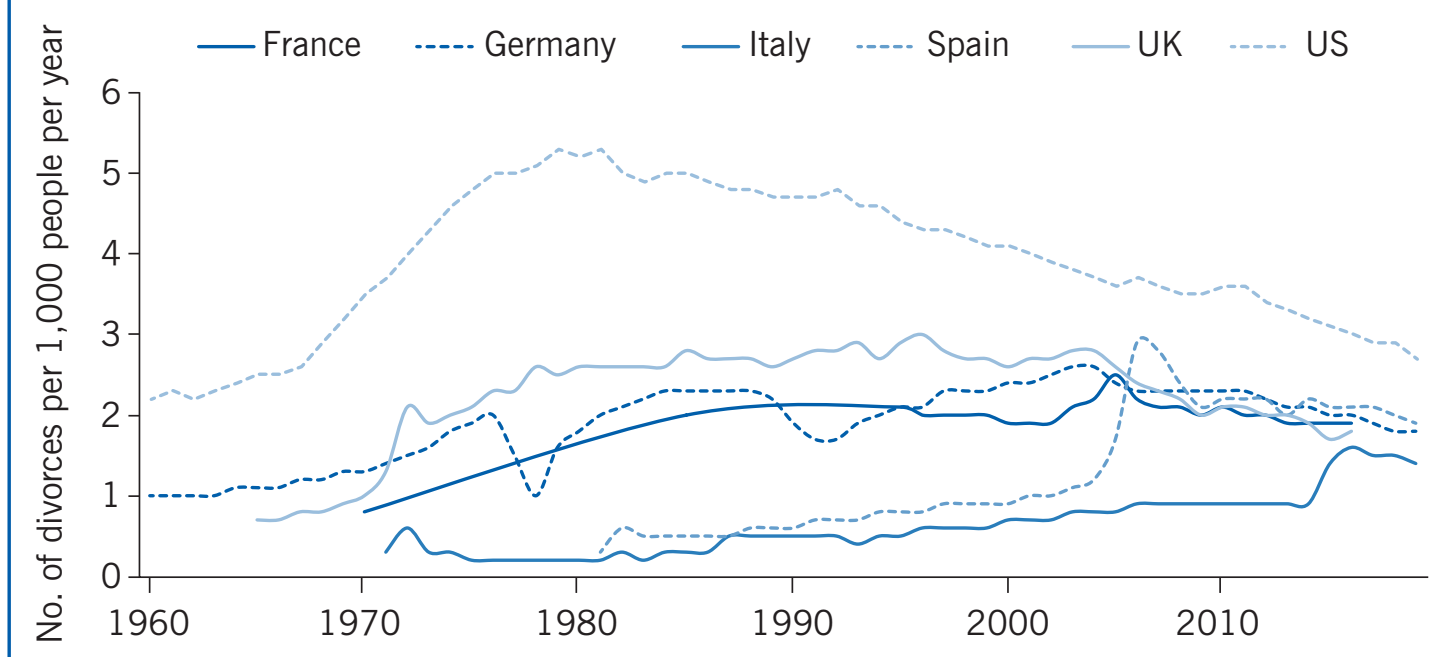

Source: Authors' own compilation using data from: Eurostat. Online at https://ec.europa.eu/eurostat/statistics-explained/ index.php?title=Marriage_and_divorce_statistics\#Fewer_marriages.2C_more_divorces (for European countries); Carter et al. (2006), for the period 1960-1995, US Census Bureau (2007), for the period 1996-2004, and CDC. Online at: https://www.cdc.gov/nchs/data/dvs/national-marriage-divorce-rates-00-19.pdf, for the period 2005 to present (for the US). 
until 2014, and then rising to about 1.5. Similarly, Spain exhibited slightly higher divorce rates than Italy, but following the 2005 reform, the level steadily increased to almost three divorces a year per 1,000 people. France, Germany, Spain, and the UK display similar levels as well as trends, with a divorce rate around two a year per 1,000 people in the late 2010s.

A few careful quantitative studies have analyzed the effect of divorce laws on divorce rates, using data for US states [2] and for several European countries [1]. These studies suggest that the introduction of no-fault and unilateral divorce leads to increases in the divorce rate, at least in the short term (for couples already married at the time of the reform). However, the studies also conclude that divorce law reforms are not the main driver of the widespread increase in divorce rates during the second half of the 20th century. For instance, the European study concludes that divorce law reforms in Europe can account for less than half of the overall increase in divorce rates between 1950 and 2003.

However, there may be no reason to care particularly about the divorce rate itself. It could be that when divorce is very restricted or banned couples break up at the same rate as under more liberal divorce laws, but they do so without the legal stamp of a divorce. If this is the case, then perhaps divorce law is irrelevant, or it matters only for deciding or implementing economic transfers across former spouses or child custody arrangements.

Recent studies suggest that this is not the case, however, and that in fact changes in the legal regulation of divorce can have important social effects above and beyond the impact on marital breakdown rates. The best research studies in this area exploit "natural experiments" to answer these questions. For instance, to detect potential changes in trends coinciding with the timing of the divorce law reforms, studies compare the evolution of social trends over time across different US states or European countries that liberalized divorce laws at different times.

The key insight offered by economic theory is that, even if divorce laws did not affect the number of divorces or separations (or even if this effect was small), reducing the cost of divorce or otherwise changing the rules could still affect the individual behavior of married and even unmarried people. For instance, imagine a married couple who experience disagreements. The economic models of intrahousehold bargaining suggest that the bargaining power of each spouse (when negotiating over any kind of household decision, such as how to spend or save their money) depends on the credibility of the threat to leave the marriage (to divorce). Thus, for example, a law that changed the divorce requirement from mutual consent to unilateral decision could have important effects on the relative bargaining power of husband and wife, improving the situation of the spouse less interested in preserving the marriage. This in turn could affect a range of household decisions.

The following sections illustrate some of the results in this recent literature for several different outcomes: female labor supply, marriage and fertility decisions, child well-being, household saving, and domestic violence.

\section{Female labor supply}

Several recent studies take seriously the possibility that changes in divorce laws can affect the behavior of married individuals, in particular a wife's employment decisions-and not only for women who end up divorcing. A relevant study examines the impact on 
labor supply of Ireland's legalization of divorce in 1996 [3]. After the legislative reform, the overall rate of separations and divorces increased significantly, although marital dissolution rates remained extremely low among very religious (Catholic) couples. These couples were used as the control group, and married women in non-religious couples were used as the treatment group. After divorce was legalized, married women in nonreligious couples (for whom the risk of divorce increased) were significantly more likely to work than before the reform, while women in religious couples (less affected by the legalization of divorce) were no more likely to work than before. One possible explanation is that the increase in the probability of a divorce raised the returns to investing in work experience for married women if they anticipated that divorce could have negative economic consequences for them.

Similarly, another study finds that women who are exposed to unilateral divorce at later ages tend to get divorced later in life and display different employment and retirement patterns. Those women with a prior low risk of divorce have greater probability of full-time employment later during their life, but a significantly lower level of retirement wealth. For all other women, a tardy exposure to divorce risk does not impact full-time employment after the age of 50 but is associated with a higher investment in education after marriage. Lastly, women facing a higher divorce risk usually respond by remaining employed during marriage as a precaution-thus insuring themselves against a potential future income loss due to divorce-allowing them to retire earlier [4].

However, the impact of divorce law on labor supply may depend on the specific details of the reform; in particular, on the expected economic effects of a potential divorce. For instance, a prominent study evaluates the effects of the introduction of unilateral divorce across US states [5]. In states that imposed an equal division of property between the spouses, unilateral divorce led to lower employment rates among married women. The study concludes that because an equal division of property (combined with unilateral divorce) does not benefit all women, in the sense of insuring them against a drop in consumption at divorce, a clear definition of property rights, as in title-based regimes, might be preferable.

Other than the time spent in employment, divorce may also affect the share of household work through bargaining effects. Recent research finds that unilateral divorce reforms decrease overall marital investment, as both men and women reduce their household work. Nevertheless, the interaction of unilateral divorce and joint custody laws leads to an increase in the share of household work among fathers who stand to lose custody of their children upon divorce, with the largest effects being visible in those groups with a higher probability of divorce [6].

\section{Marriage and fertility rates}

The finding that divorce rates increase shortly after reforms that make divorce easier is driven by what can be referred to as a "pipeline effect"-the dissolution of marriages already in place at the time of the divorce law reform. In the long term, however, it is possible that divorce laws might affect the incentives to marry, but the direction of the effect is not clear. On the one hand, easier divorce may lead to more marriages, since it lowers the cost of exiting marriage. On the other hand, easier divorce also devalues the institution of marriage as a commitment device, making it less attractive, which may 
lead to fewer marriages. Related research suggests that the second effect dominates: unilateral divorce reduces the marriage rate, but as a result, post-reform marriages are of higher quality, which may lead to lower divorce rates in the long term, through what the study refers to as a "selection effect" [7].

Other studies have addressed the potential effects of divorce laws on fertility rates. The results strongly suggest that liberalizing divorce lowers fertility. For instance, a study of fertility rates across 18 European countries between 1960 and 2006 finds strong evidence that fertility rates fell permanently following reforms that made divorce easier [8]. Other studies have also found a decrease in fertility following the introduction of unilateral divorce in US states, regardless of property division laws. This effect is attributed to the lower cost of divorce devaluing investment in marriage.

Marriage and fertility rates are also affected by legal provisions on child custody. Reforms favoring joint custody have been shown to lead to higher marriage rates as well as higher fertility rates (and, perhaps as a result, lower female labor force participation) [9]. The author of the study interprets these findings as the result of joint custody laws improving the bargaining position of husbands and thus increasing the value of marriage and children for men.

\section{Children}

When thinking about divorce law, identifying the effects on the well-being of children, both in the short and the long term, is a natural concern. The evidence suggests that liberalizing divorce does not have positive long-term effects on children, at least for children who were already born at the time of the policy change. For instance, a 2004 study finds that children who grew up in US states allowing unilateral divorce decided to marry and bear children earlier, besides attaining fewer years of education and lower family income (as adults) than children raised in states where unilateral divorce was not permitted [10]. These conclusions have been recently challenged by new data which show that unilateral divorce leads to a lower probability of ever starting a family and has little impact on adults' completed education. Another study finds that children who were young when unilateral divorce became available are more likely to commit violent crimes later in life, resulting in higher crime rates ten years after the reforms in states that introduced unilateral divorce [11]. The study attributes this effect to an increase in poverty among divorced mothers affected by the reforms.

The evidence thus suggests that unilateral divorce reforms may harm children in the long term, at least in the case of children who were born before the reforms. What are the mechanisms through which these reforms adversely affect children later in life? Because in the short term making divorce easier increases the divorce rate [1], [2], parental divorce would be the main suspect, assuming that divorce in itself has a negative causal effect on child outcomes. In this vein, a recent study suggests that boys exhibit fewer effects of parental divorce on their fertility or marriage behavior, but experience higher rates of early mortality and worse labor market outcomes. Girls, on the other hand, have a higher likelihood of pregnancy up to their early 20s but there is little effect on their early marriage rates, with subsequent out-of-wedlock childbearing and higher employment probability at that age [12]. 
Some studies focus on the non-economic implications of parental divorce, such as those on psychological well-being, interaction with the non-custodial parent, or family reconstitution. A recent study compares the effects of divorce and parental job loss on children's university admission outcomes, and concludes that the psychological shock dominates economic factors. Similarly, another study evaluates the effects of a policy change in the US aimed at decreasing child support in cases of joint custody. They find that, even when reductions in child support are associated with children spending more days with their fathers, they have a negative impact on children's educational attainment and health outcomes. These effects might be driven by differences in parental time: custodian fathers paying lower child support work less and spend more quality time with their children, but also take children's time away from their mothers-especially so for those who work less-who would otherwise have spent more time taking care of them [13].

Overall, a number of studies have shown that parental divorce per se might cause negative outcomes for children, although evidence remains scarce. Thus, it is likely that there are additional, more indirect channels at play, such as parental labor supply, household spending and saving behavior, and parental investments in children.

\section{Household saving}

A few studies have investigated the effects of divorce laws on other economic decisions in households headed by a married couple, such as asset accumulation (saving). One study exploits data from Ireland and finds that a "side effect" of the 1996 legalization of divorce was an increase in household savings among married couples (even those who did not divorce) [14]. A priori, an increase in the risk of divorce may generate incentives both to save more (in anticipation of higher future expenditures) and to save less (to avoid having to split the assets in case of a breakup). The results suggest that the pro-saving effect dominates. A more recent study also suggests that the introduction of unilateral divorce in US states led to higher household savings [5].

\section{Domestic violence}

The evidence suggests that divorce law can have important indirect economic effects. But the indirect effects may go beyond household economic decisions. Studies using data for the US and Spain show that the introduction of unilateral divorce, by altering the bargaining power between spouses, can affect the incidence of domestic violence (and suicide rates) [15]. For instance, as the cost of divorce fell following a reform of Spain's divorce law in 2005 (which lifted the requirement for a period of separation before a divorce can be granted), the incidence of domestic violence declined significantly for married partners (even those who stayed together) compared with unmarried cohabiting couples (not affected directly by divorce laws) in the control group [15].

\section{LIMITATIONS AND GAPS}

Some consensus seems to have emerged on the impact of no-fault and unilateral divorce on divorce rates: both types of reforms have probably raised divorce rates in the short 
term for pre-existing marriages. The evidence also suggests that these reforms have had negative long-term effects for children born shortly before the law changed. However, more research is needed in at least three areas.

First, the results are not clear-cut regarding the impact of unilateral divorce on female employment. An early influential study finds no independent impact of unilateral divorce on female labor supply, while more recent studies find that unilateral divorce increases female labor force participation, regardless of property division laws. On the other hand, a re-analysis of US data suggests that unilateral divorce combined with equal division of property leads to lower female employment [5]. Future research should do more to understand the sources of these diverging results.

The second open issue concerns the effects of easier divorce on children-both those born before the reform and those born after it. The evidence suggests that reforms introducing unilateral divorce tend to be harmful over the long term to children born before the reforms. However, the mechanisms through which these reforms adversely affect children later in life are not well understood. In the short term, making divorce easier increases divorce rates, but research has shown that parental divorce per se probably does not have large effects on child outcomes. Moreover, only a very small fraction of children are affected by the (temporary) increase in divorce rates. What else is driving these effects? This is still an open question, and the answer is probably related to the fact that divorce reforms affect individual and household behavior in various ways beyond divorce and separation rates, as are discussed here. The missing piece is to identify which of these behavioral changes (or which combination of them) ends up harming children in the long term. For policy design, it is important to learn more about why and how these children were harmed by easier divorce laws (did it have to do with labor supply, savings, or other changes in the household?), so as to provide them with better targeted support. Future studies may need to take a broader approach that jointly considers various potential mechanisms (such as those reviewed in this article) to answer this question.

A final question that is yet to be answered conclusively is how easier divorce affects children born to couples who married after the introduction of unilateral divorce. If the quality of the new marriages is higher, as suggested by recent research, then the children of these unions could potentially have better outcomes on average.

\section{SUMMARY AND POLICY ADVICE}

A number of studies have analyzed the social impact of recent reforms in divorce legislation across countries. The results suggest that the introduction of unilateral divorce raised divorce rates, at least temporarily, and that unilateral divorce reforms probably had some negative effects for couples who were "trapped" in the transition (married under the previous divorce law regime and "surprised" by the reforms), including negative long-term effects for children born shortly before the legal changes. However, no-fault and unilateral divorce reforms cannot explain the large increases in divorce rates in many countries in the second half of the 20th century. In addition, a number of studies have found that legal, easy, unilateral divorce may have positive economic and social consequences, including increasing saving rates among married individuals and reducing the level of intrahousehold conflict and domestic violence. Moreover, in the long term, unilateral divorce seems to have led to better (if fewer) marriages, probably with lower 
divorce rates, suggesting that the overall long-term effects of the reforms are likely to be welfare-enhancing. Also, recent reforms favoring joint child custody seem to have encouraged marriage and fertility.

Thus, the available evidence offers little hope that reinstating fault-based or mutualagreement divorce laws, or more generally making divorce harder, would dramatically reverse the so-called "breakdown of the traditional family." However, it is worth noting that unilateral divorce combined with equal division of property, as well as reforms that favor joint custody of children, may depress female employment, at least for some groups of women, which some countries may want to avoid. For instance, China (where it is not uncommon that spouses end up living in houses purchased prior to marriage, titled solely under the soon-to-be husband's name) effectively changed the pre-marital housing property division upon divorce from an equal-division to a title-based regime, which increased the employment probability for married women, but shifted bargaining power toward husbands. Other relevant findings, on the contrary, suggest that unilateral divorce may lead to increased equity and to fewer distortions of labor supply if combined with separate property or prenuptial agreements [5].

Finally, policymakers should keep in mind the potential effects of changes in divorce laws on children, both in the short and long term. The evidence indicates that introducing unilateral divorce will potentially improve outcomes for children born to couples who were married after the reforms were introduced, while it may harm children born shortly before the reforms. Although the channels are still not well understood, this negative effect may be the consequence, at least in part, of the temporary increase in divorce rates following reforms that make divorce easier. Thus, policies that facilitate income and other forms of support for children of parents who divorce soon after reforms in the divorce law may help alleviate such effects.

\section{Acknowledgments}

The authors thank an anonymous referee and the IZA World of Labor editors for their helpful suggestions on previous drafts. Version 2 of the article examines a change to Italian divorce law, discusses the effects of divorce on women's income in retirement, household work, and the probability of starting a family, updates the figures, and adds new "Key references" [4], [6], [12], [13].

\section{Competing interests}

The IZA World of Labor project is committed to the IZA Code of Conduct. The authors declare to have observed the principles outlined in the code.

(c) Libertad Gonzalez and Alicia De Quinto 


\section{REFERENCES}

\section{Further reading}

Becker, G. A Treatise on the Family. Cambridge, MA: Harvard University Press, 1981.

Dnes, A. W., and R. Rowthorn (eds). The Law and Economics of Marriage and Divorce. Cambridge: Cambridge University Press, 2002.

\section{Key references}

[1] González, L., and T. Viitanen. "The effect of divorce laws on divorce rates in Europe." European Economic Review 53:2 (2009): 127-138.

[2] Wolfers, J. "Did unilateral divorce laws raise divorce rates? A reconciliation and new results." American Economic Review 96:5 (2006): 1802-1820.

[3] Bargain, O., L. González, C. Keane, and B. Özcan. "Female labor supply and divorce: New evidence from Ireland." European Economic Review 56:8 (2012): 1675-1691.

[4] Olivetti, C., and D. Rotz. "Changes in marriage and divorce as drivers of employment and retirement of older women." In: Women Working Longer: Increased Employment at Older Ages. Cambridge, MA: NBER, 2016.

[5] Voena, A. "Yours, mine and ours: Do divorce laws affect the intertemporal behavior of married couples?" American Economic Review 105:8 (2015): 2295-2332.

[6] Roff, J. Cleaning in the Shadow of the Law? Bargaining, Marital Investment, and the Impact of Divorce Law on Husbands' Intra-household Work. IZA Discussion Paper No. 10527, 2017.

[7] Rasul, I. "Marriage markets and divorce laws." Journal of Law, Economics and Organization 22:1 (2006): 30-69.

[8] Bellido, H., and M. Marcen. "Divorce laws and fertility." Labour Economics 27:C (2014): 56-70.

[9] Halla, M. "The effect of joint custody on family outcomes." Journal of the European Economic Association 11:2 (2013): 278-315.

[10] Gruber, J. "Is making divorce easier bad for children? The long-run implications of unilateral divorce." Journal of Labor Economics 22:4 (2004): 799-833.

[11] Cáceres-Delpiano, J., and E. Giolito. "The impact of unilateral divorce on crime." Journal of Labor Economics 30:1 (2012): 215-248.

[12] Frimmel, W., M. Halla, and R. Winter-Ebmer. How Does Parental Divorce Affect Children's Long-term Outcomes? IZA Discussion Paper No. 9928, 2016.

[13] Fernández-Kranz, D., J. Roff, and H. Sun. Can Reduced Child Support Make Joint Custody Bad for Children? The Role of Economic Incentives in U.S. Divorce Law on Child Outcomes. IZA Discussion Paper No. 12025, 2018.

[14] González, L., and B. Özcan. "The risk of divorce and household saving behaviour." Journal of Human Resources 48:2 (2013): 404-434.

[15] Brassiolo, P. "Domestic violence and divorce law: When divorce threats become credible." Journal of Labor Economics 34:2 (2016): 443-477.

\section{Online extras}

The full reference list for this article is available from:

https://wol.iza.org/articles/should-divorce-be-easier-or-harder

View the evidence map for this article:

https://wol.iza.org/articles/should-divorce-be-easier-or-harder/map 